\title{
Front Matter: Volume 7976
}

, "Front Matter: Volume 7976," Proc. SPIE 7976, Electroactive Polymer Actuators and Devices (EAPAD) 2011, 797601 (27 April 2011); doi: 10.1117/12.894740

SPIE Event: SPIE Smart Structures and Materials + Nondestructive Evaluation and Health Monitoring, 2011, San Diego, California, United States 


\title{
PROCEEDINGS OF SPIE
}

\section{Electroactive Polymer Actuators and Devices (EAPAD) 2011}

\author{
Yoseph Bar-Cohen \\ Federico Carpi \\ Editors
}

\section{7-10 March 2011}

San Diego, California, United States

Sponsored by

SPIE

Cosponsored by

American Society of Mechanical Engineers (United States)

Cooperating Organizations

Intelligent Materials Forum (Japan)

Jet Propulsion Laboratory (United States)

National Science Foundation (United States)

Published by

SPIE 
The papers included in this volume were part of the technical conference cited on the cover and title page. Papers were selected and subject to review by the editors and conference program committee. Some conference presentations may not be available for publication. The papers published in these proceedings reflect the work and thoughts of the authors and are published herein as submitted. The publisher is not responsible for the validity of the information or for any outcomes resulting from reliance thereon.

Please use the following format to cite material from this book:

Author(s), "Title of Paper," in Electroactive Polymer Actuators and Devices (EAPAD) 2011, edited by Yoseph Bar-Cohen, Federico Carpi, Proceedings of SPIE Vol. 7976 (SPIE, Bellingham, WA, 2011) Article CID Number.

ISSN 0277-786X

ISBN 9780819485380

Published by

SPIE

P.O. Box 10, Bellingham, Washington $98227-0010$ USA

Telephone +1 3606763290 (Pacific Time) · Fax +1 3606471445

SPIE.org

Copyright (@ 2011, Society of Photo-Optical Instrumentation Engineers

Copying of material in this book for internal or personal use, or for the internal or personal use of specific clients, beyond the fair use provisions granted by the U.S. Copyright Law is authorized by SPIE subject to payment of copying fees. The Transactional Reporting Service base fee for this volume is $\$ 18.00$ per article (or portion thereof), which should be paid directly to the Copyright Clearance Center (CCC), 222 Rosewood Drive, Danvers, MA 01923. Payment may also be made electronically through CCC Online at copyright.com. Other copying for republication, resale, advertising or promotion, or any form of systematic or multiple reproduction of any material in this book is prohibited except with permission in writing from the publisher. The CCC fee code is 0277-786X/11/ \$18.00.

Printed in the United States of America.

Publication of record for individual papers is online in the SPIE Digital Library.

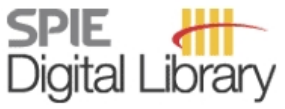

SPIEDigitalLibrary.org

Paper Numbering: Proceedings of SPIE follow an e-First publication model, with papers published first online and then in print and on CD-ROM. Papers are published as they are submitted and meet publication criteria. A unique, consistent, permanent citation identifier (CID) number is assigned to each article at the time of the first publication. Utilization of CIDs allows articles to be fully citable as soon they are published online, and connects the same identifier to all online, print, and electronic versions of the publication. SPIE uses a six-digit CID article numbering system in which:

- The first four digits correspond to the SPIE volume number.

- The last two digits indicate publication order within the volume using a Base 36 numbering system employing both numerals and letters. These two-number sets start with 00, 01, 02, 03, 04 , 05, 06, 07, 08, 09, OA, OB ... 0Z, followed by 10-1Z, 20-2Z, etc.

The CID number appears on each page of the manuscript. The complete citation is used on the first page, and an abbreviated version on subsequent pages. Numbers in the index correspond to the last two digits of the six-digit CID number. 


\title{
Contents
}

\section{Part One}

\author{
xiii Conference Committee \\ xviii Introduction
}

\section{EAP AS EMERGING ACTUATORS}

$797602 \quad$ Walking with springs (Keynote Paper) [7976-01]

T. G. Sugar, Arizona State Univ. (United States); K. W. Hollander, SpringActive, Inc. (United States); J. K. Hitt, United States Military Academy (United States)

797603 Dielectric elastomers: from the beginning of modern science to applications in actuators and energy harvesters (Invited Paper) [7976-02]

R. Baumgartner, C. Keplinger, R. Kaltseis, R. Schwödiaver, S. Baver, Johannes Kepler Univ. Linz (Austria)

797604 Directions for development of the field of electroactive polymer (EAP) [7976-03]

Y. Bar-Cohen, Jet Propulsion Lab. (United States)

\section{ENERGY HARVESTING SPECIAL SESSION: PART I}

797605 From boots to buoys: promises and challenges of dielectric elastomer energy harvesting (Invited Paper) [7976-04]

R. D. Kornbluh, R. Pelrine, H. Prahlad, A. Wong-Foy, B. McCoy, S. Kim, J. Eckerle, T. Low, SRI International (United States)

797606 Acrylic interpenetrating polymer network dielectric elastomers for energy harvesting [7976-05]

P. Brochu, X. Niu, Q. Pei, Univ. of California, Los Angeles (United States)

797607 Characterization of the effect of energy harvesting on the dynamic response of dielectric elastomers [7976-06]

H. L. Lai, C.-A. Tan, Y. Xu, Wayne State Univ. (United States)

797608 Energy harvesting from flutter instabilities of heavy flags in water through ionic polymer metal composites [7976-07]

A. Giacomello, M. Porfiri, Polytechnic Institute of New York Univ. (United States)

\section{ENERGY HARVESTING SPECIAL SESSION: PART II}

7976 OB Realizing the potential of dielectric elastomer generators [7976-10]

T. McKay, B. O'Brien, The Univ. of Auckland (New Zealand); E. Calius, Industrial Research Ltd.

(New Zealand); I. Anderson, The Univ. of Auckland (New Zealand) 
7976 OC Circuit design considerations for regulating energy generated by dielectric elastomer generators [7976-11]

H. C. Lo, T. Mckay, B. M. O'Brien, The Univ. of Auckland (New Zealand); E. Calius, Industrial Research Ltd. (New Zealand); I. Anderson, The Univ. of Auckland (New Zealand)

7976 OD Battery modeling for energy harvesting system [7976-12]

R. Tiwari, N. Buch, E. Garcia, Cornell Univ. (United States)

EUROPEAN SCIENTIFIC NETWORK FOR ARTIFICIAL MUSCLE (ESNAM) SPECIAL SESSION: ENERGY HARVESTING

7976 OG Dielectric elastomer materials for actuators and energy harvesting [7976-15]

D. M. Opris, M. Molberg, F. Nüesch, C. Löwe, C. Walder, B. Fischer, EMPA (Switzerland)

$7976 \mathrm{OH}$ Evaluation and optimization of energy harvesting cycles using dielectric elastomers [7976-16]

C. Graf, J. Maas, Hochschule Ostwestfalen-Lippe Univ. of Applied Sciences (Germany)

7976 Ol Scalable design of DEAP for energy harvesting utilizing PolyPower [7976-17]

M. Benslimane, M. J. Tryson, J. Oubak, H.-E. Kiil, Danfoss PolyPower A/S (Denmark)

ESNAM SPECIAL SESSION: MATERIALS AND DEVICES I

7976 0J Molecular level materials design for improvements of actuation properties of dielectric elastomer actuators (Invited Paper) [7976-18]

G. Kofod, H. Stoyanov, M. Kollosche, S. Risse, H. Ragusch, D. N. McCarthy, R. Waché,

D. Rychkov, M. Dansachmüller, Univ. of Potsdam (Germany)

7976 OK Conducting IPN actuators for biomimetic vision system (Invited Paper) [7976-19]

N. Festin, Univ. de Cergy-Pontoise (France) and Brain Vision Systems (France); C. Plesse,

C. Chevrot, D. Teyssié, Univ. de Cergy-Pontoise (France); P. Pirim, Brain Vision Systems

(France); F. Vidal, Univ. de Cergy-Pontoise (France)

$7976 \mathrm{OL} \quad$ Electro-mechanical modeling of dielectric elastomer transducers with micro-structured electrodes [7976-20]

A. Schmidt, ETH (Switzerland) and EMPA (Switzerland); A. Bergamini, C. Jordi, G. Kovacs, EMPA (Switzerland); E. Mazza, ETH (Switzerland) and EMPA (Switzerland)

7976 OM Electroactive semi-interpenetrating polymer networks architecture with tunable IR reflectivity [7976-21]

C. Chevrot, D. Teyssié, P. Verge, L. Goujon, Univ. de Cergy-Pontoise (France); F. Tran-Van, Univ. F. Rabelais (France); F. Vidal, P. H. Aubert, S. Peralta, Univ. de Cergy-Pontoise (France); L. Sauques, Délégation Générale de l'Armement (France)

7976 ON DEA material enhancement with dipole grafted PDMS networks [7976-22]

S. Risse, Univ. of Potsdam (Germany); B. Kussmaul, H. Krüger, Fraunhofer IAP (Germany);

R. Waché, G. Kofod, Univ. of Potsdam (Germany) 
797600 Carbon aerogel based electrode material for EAP actuators [7976-23]

F. Kaasik, J. Torop, Univ. of Tartu (Estonia); A.-L. Peikolainen, M. Koel, Tallinn Univ. of Technology (Estonia); A. Aabloo, Univ. of Tartu (Estonia)

7976 OP Lifetime of dielectric elastomer stack actuators [7976-24]

P. Lotz, Technische Univ. Darmstadt (Germany); M. Matysek, Philips Research Europe (Germany); H. F. Schlaak, Technische Univ. Darmstadt (Germany)

7976 OQ Self-sensing properties of carbon-polymer composite (CPC) actuators [7976-25]

K. Kruusamäe, A. Punning, A. Aabloo, Univ. of Tartu (Estonia)

ESNAM SPECIAL SESSION: MATERIALS AND DEVICES II

7976 OR Miniaturized EAPs with compliant electrodes fabricated by ion implantation (Invited Paper) [7976-26]

H. Shea, Ecole Polytechnique Fédérale de Lausanne (Switzerland)

7976 OS Parameter dependence of an electro-mechanical breakdown model for insulating elastomeric films [7976-27]

M. Kollosche, H. Stoyanov, S. Best, H. Ragusch, G. Kofod, Univ. of Potsdam (Germany)

\section{FIELD ACTIVATED EAP}

7976 OT Transparent active skin [7976-77]

H.-Y. Kwon, K. J. An, J. Kang, V. H. Phuc, N. C. Toan, B. C. Kim, J. A. Chung, B. H. Hong, J. Choi, H. Moon, J. Koo, J. Nam, H. R. Choi, Sungkyunkwan Univ. (Korea, Republic of)

7976 OU Multilayer dielectric elastomer actuators with ion implanted electrodes [7976-29]

A. Punning, S. Akbari, M. Niklaus, H. Shea, Ecole Polytechnique Fédérale de Lausanne (Switzerland)

7976 OV Multi-walled carbon nanotubes (MWCNT) as compliant electrodes for dielectric elastomer actuators [7976-30]

S.-L. Chua, X.-H. Neo, G.-K. Lau, Nanyang Technological Univ. (Singapore)

ESNAM SPECIAL SESSION: MATERIALS AND DEVICES III

7976 0X Dielectric elastomer actuators with granular coupling [7976-32]

F. Carpi, Univ. of Pisa (Italy) and Technology \& Life Institute (Italy); G. Frediani, M. Nanni, Univ. of Pisa (Italy); D. De Rossi, Univ. of Pisa (Italy) and Technology \& Life Institute (Italy)

\section{IONIC EAP}

$79760 Z$ Altering the structure of polypyrrole and the influence on electrodynamic performance [7976-34]

D. Melling, S. Wilson, Cranfield Univ. (United Kingdom); M. Berggren, E. W. H. Jager, Linköping Univ. (Sweden) 
797610 Refreshable tactile displays based on bistable electroactive polymer [7976-35]

X. Niu, P. Brochu, B. Salazar, Q. Pei, Univ. of California, Los Angeles (United States)

797611 PVDF core-free actuator for Braille displays: design, fabrication process, and testing [7976-36]

T. Levard, P. J. Diglio, S.-G. LU, C. D. Rahn, Q. M. Zhang, The Pennsylvania State Univ. (United States)

797612 Combined driving and sensing circuitry for dielectric elastomer actuators in mobile applications [7976-37]

M. Matysek, Philips Research Europe (Netherlands); H. Haus, H. Moessinger, Technische Univ. Darmstadt (Germany); D. Brokken, Philips Research Europe (Netherlands); P. Lotz,

H. F. Schlaak, Technische Univ. Darmstadt (Germany)

IONIC EAP (CONTINUED)

797613 Effects of TEOS content on the mechanical property of ionic polymer metal composite [7976-38]

Q. He, M. Yu, D. Guo, Z. Dai, Nanjing Univ. of Aeronautics and Astronautics (China)

797614 Frequency response of IPMC actuator with palladium electrode [7976-39]

T. Kobayashi, M. Omiya, Keio Univ. (Japan)

797615 Millimeter thick ionic polymer membrane-based IPMCs with bimetallic Pd-Pt electrodes [7976-40]

V. Palmre, S. J. Kim, K. Kim, Univ. of Nevada, Reno (United States)

HAPTIC AND BRAILLE DISPLAYS II

797616 Opportunities for micro-steerable catheters and tactile feedback technology with high performance electrostrictive EAPs [7976-41]

S. Liu, B. C. Zellers, D. Anderson, Strategic Polymer Sciences, Inc. (United States)

797617 Haptic device development based on electro static force of cellulose electro active paper [7976-42]

G. Yun, Inha Univ. (Korea, Republic of); S.-Y. Kim, Korea Univ. of Technology and Education (Korea, Republic of); S.-D. Jang, D.-G. Kim, J. Kim, Inha Univ. (Korea, Republic of)

797618 Opportunities of hydrostatically coupled dielectric elastomer actuators for haptic interfaces [7976-43]

F. Carpi, Univ. of Pisa (Italy) and Technology \& Life Institute (Italy); G. Frediani, Univ. of Pisa (Italy); D. De Rossi, Univ. of Pisa (Italy) and Technology \& Life Institute (Italy) 
IONIC EAP (CONTINUED)

797619 Multi-component single-substrate conducting polymer actuation systems and fabrication techniques [7976-44]

E. Paster, B. P. Ruddy, P. V. Pillai, I. W. Hunter, Massachusetts Institute of Technology (United States)

7976 1C Electrostatic and thermal segmentation of multi-segment IPMC sensor-actuators [7976-47]

J. Rossiter, Univ. of Bristol (United Kingdom); T. Mukai, RIKEN (Japan)

ESNAM SPECIAL SESSION: APPLICATIONS AND CONTROLS

7976 IF Accurate free-form surface actuation using a non-pre-stretched silicone dielectric polymer actuator [7976-50]

F. M. H. Crompvoets, D. Brokken, H. de Koning, W. M. Martam, Philips Research (Netherlands)

7976 IG Comparison of dielectric materials for the activation of a macro-scale hinge configuration [7976-51]

C. Jordi, A. Schmidt, EMPA (Switzerland) and ETH (Switzerland); G. Kovacs, EMPA

(Switzerland); P. Ermanni, ETH (Switzerland)

7976 1H Control concepts for dielectric elastomer actuators [7976-52]

J. Maas, C. Graf, L. Eitzen, Ostwestfalen-Lippe Univ. of Applied Sciences (Germany)

797611 Dielectric elastomers for active vibration control applications [7976-53]

S. Herold, W. Kaal, T. Melz, Fraunhofer Institute for Structural Durability and System Reliability (Germany)

7976 1J Physical model-based internal model control of a DE actuator [7976-54]

R. Sarban, Danfoss PolyPower A/S (Denmark) and Univ. of Southern Denmark (Denmark);

R. W. Jones, Univ. of Southern Denmark (Denmark)

7976 IK Dielectric elastomer stack actuators for integrated gas valves [7976-106]

K. Flittner, M. Schlosser, H. F. Schlaak, Technische Univ. Darmstadt (Germany)

7976 IL Polypyrrol/chitosan hydrogel hybrid microfiber as sensing artificial muscle [7976-56]

Y. A. Ismail, Univ. of Nizwa (Oman); J. G. Martínez, Univ. Politécnica de Cartagena (Spain);

A. S. Al Harrasi, Univ. of Nizwa (Oman); S. J. Kim, Hanyang Univ. (Korea, Republic of);

T. F. Fernández Otero, Univ. Politécnica de Cartagena (Spain)

\section{Part Two}

MODELING AND ANALYSIS OF EAP

7976 iN Constitutive relation and electromechanical stability of compressible dielectric elastomer [7976-58]

L. Liu, Harbin Institute of Technology (China); X. Liang, Institute of Process Engineering

(China); K. Yang, C. Wu, Z. Liu, S. Sun, Y. Liu, J. Leng, Harbin Institute of Technology (China) 
797610 Chemo-electro-mechanical modeling of pH-sensitive hydrogels [7976-59]

T. Wallmersperger, Technische Univ. Dresden (Germany); K. Keller, B. Kröplin, Univ. Stuttgart

(Germany); M. Günther, G. Gerlach, Technische Univ. Dresden (Germany)

7976 IP Charge modeling of ionic polymer-metal composites for dynamic curvature sensing [7976-60]

Y. Bahramzadeh, M. Shahinpoor, Univ. of Maine (United States)

7976 1Q A validated finite element model of a soft artificial muscle motor [7976-61]

T. C. H. Tse, B. O'Brien, T. McKay, Auckland Bioengineering Institute (New Zealand);

I. A. Anderson, Auckland Bioengineering Institute (New Zealand) and The Univ. of Auckland (New Zealand)

7976 IR A viscoelastic model for dielectric elastomers based on a continuum mechanical formulation and its finite element implementation [7976-62]

A. Bueschel, Karlsruhe Institute of Technology (Germany); S. Klinkel, Technische Univ.

Kaiserslautern (Germany); W. Wagner, Karlsruhe Institute of Technology (Germany)

7976 is Modeling and designing IPMCs for twisting motion: electromechanical and mechanoelectrical transduction [7976-63]

D. Pugal, K. J. Kim, K. K. Leang, V. Palmre, Univ. of Nevada, Reno (United States)

\section{APPLICATIONS OF EAP I: FIELD ACTIVATED}

7976 IT Flexidrive: a soft artificial muscle motor (Invited Paper) [7976-64]

I. A. Anderson, Auckland Bioengineering Institute (New Zealand) and The Univ. of Auckland (New Zealand); T. C. H. Tse, T. Inamura, B. O'Brien, T. McKay, T. Gisby, Auckland

Bioengineering Institute (New Zealand)

$79761 U$ In-plane DEAP stack actuators for optical MEMS applications [7976-65]

J. Brunne, S. Kazan, U. Wallrabe, Univ. of Freiburg (Germany)

NON-EAP ACTUATORS I

7976 IV Determination of the sinking and terminating points of action unit on humanoid skull through GFEAD [7976-66]

Y. Tadesse, S. Priya, Virginia Polytechnic Institute and State Univ. (United States)

APPLICATIONS OF EAP I: FIELD ACTIVATED (CONTINUED)

7976 IY Relaxor fluorinated polymers: novel applications and recent developments [7976-69] F. Baver, D. Dos Santos, Piézotech S.A.S. (France); Q. Zhang, The Pennsylvania State Univ. (United States)

797612 Antagonistic dielectric elastomer actuator for biologically-inspired robotics [7976-70] A. T. Conn, J. Rossiter, Univ. of Bristol (United Kingdom) and Bristol Robotics Lab. (United Kingdom) 
797620 Closed loop control of dielectric elastomer actuators [7976-71]

T. A. Gisby, B. M. O'Brien, Auckland Bioengineering Institute (New Zealand); S. Q. Xie, The Univ. of Auckland (New Zealand); E. P. Calius, Industrial Research Ltd. (New Zealand);

I. A. Anderson, Auckland Bioengineering Institute (New Zealand) and The Univ. of Auckland (New Zealand)

$797621 \quad$ Dielectric elastomer memory [7976-72]

B. M. O'Brien, T. G. McKay, S. Q. Xie, The Univ. of Auckland (New Zealand); E. P. Calius, Industrial Research Ltd. (New Zealand); I. A. Anderson, The Univ. of Auckland (New Zealand)

797622 Modelling approaches for a novel balloon-shape actuator made of electroactive polymers [7976-73]

M. Soleimani, J. Aristizabal, C. Menon, Simon Fraser Univ. (Canada)

\section{APPLICATIONS OF EAP II: IONIC EAP}

797623 A bionic eye actuated by ionic polymer-metal composite (IPMC) artificial muscle [7976-74] M. YU, Y. Li, Q. He, L. Song, Z. Dai, Nanjing Univ. of Aeronautics and Astronautics (China)

797624 Design and development of bio-inspired underwater jellyfish like robot using ionic polymer metal composite (IPMC) actuators [7976-75]

B. Akle, Lebanese American Univ. (Lebanon); J. Najem, D. Leo, Virginia Polytechnic Institute and State Univ. (United States); J. Blottman, Naval Undersea Warfare Ctr. (United States)

797625 Multilayered polypyrrole-gold-polyvinylidene fluoride composite actuators [7976-76] C. F. Smith, S. C. Yang, T. E. Long, S. Priya, Virginia Polytechnic Institute and State Univ. (United States)

797626 Cell-inspired electroactive polymer materials incorporating biomolecular materials [7976-78]

S. A. Sarles, D. J. Leo, Virginia Polytechnic Institute and State Univ. (United States)

797627 Localization of source with unknown amplitude using IPMC sensor arrays [7976-88]

A. T. Abdulsadda, F. Zhang, X. Tan, Michigan State Univ. (United States)

\section{APPLICATIONS OF EAP I: FIELD ACTIVATED (CONTINUED)}

$797628 \quad$ A dual axis shear force film sensor for robotic tactile applications [7976-79]

B. Kim, S. Shin, J. Chung, Y. Lee, J.-D. Nam, H. Moon, H. R. Choi, J. C. Koo, Sungkyunkwan Univ. (Korea, Republic of)

797629 Dielectric elastomer pump for artificial organisms [7976-80]

A. E. Bowers, Univ. of Bristol (United Kingdom) and Bristol Robotics Lab. (United Kingdom); J. M. Rossiter, Univ. of Bristol (United Kingdom); P. J. Walters, Univ. of the West of England (United Kingdom); I. A. leropoulos, Bristol Robotics Lab. (United Kingdom)

7976 2A Interconnection concepts for rigid micro-electrodes of a dielectric elastomer bending tube actuator [7976-81]

F. Wehrheim, Richard Wolf GmbH (Germany); H. F. Schlaak, Technische Univ. Darmstadt (Germany) 
7976 2B Considerations for contractile electroactive materials and actuators [7976-82]

L. Rasmussen, D. Schramm, P. Rasmussen, K. Mullally, Ras Labs, LLC (United States);

L. D. Meixler, D. Pearlman, A. Kirk, Princeton Plasma Physics Lab. (United States)

7976 2C Design of a MRI-compatible dielectric elastomer powered jet valve [7976-83]

S. Proulx, P. Chouinard, J.-P. Lucking Bigue, G. Miron, J.-S. Plante, Univ. de Sherbrooke

(Canada)

\section{APPLICATIONS OF EAP II: IONIC EAP (CONTINUED)}

7976 2D Biochemical microsensors on the basis of metabolically sensitive hydrogels [7976-84]

M. Günther, G. Gerlach, T. Wallmersperger, Technische Univ. Dresden (Germany);

F. Solzbacher, J. J. Magda, G. Lin, P. Tathireddy, M. P. Orthner, The Univ. of Utah (United States)

$79762 \mathrm{E} \quad$ Linear and bending actuation of bucky gel [7976-85]

M. Biso, A. Ansaldo, Italian Institute of Technology (Italy); V. Vintera, Univ. di Genova (Italy);

D. Ricci, Italian Institute of Technology (Italy)

7976 2G An automatic tuning method of the largest amplitude vibration of Au-nafion IPMC [7976-87] A. Itoh, Y. Mori, Tokyo Denki Univ. (Japan)

\section{POSTER SESSION}

$79762 \mathrm{H} \quad$ Inkjet printing of electroactive polymer actuators on polymer substrates [7976-89] O. Pabst, Friedrich-Schiller-Univ. Jena (Germany) and Fraunhofer Institute for Applied Optics and Precision Engineering (Germany); J. Perelaer, Friedrich-Schiller-Univ. Jena (Germany);

E. Beckert, Fraunhofer Institute for Applied Optics and Precision Engineering (Germany); U. S. Schubert, Friedrich-Schiller-Univ. Jena (Germany); R. Eberhardt, Fraunhofer Institute for Applied Optics and Precision Engineering (Germany); A. Tünnermann, Friedrich-Schiller-Univ. Jena (Germany) and Fraunhofer Institute for Applied Optics and Precision Engineering (Germany)

$797621 \quad$ Electroactive polymer devices for active vibration damping [7976-90]

C. Graf, J. Maas, Hochschule Ostwestfalen-Lippe Univ. of Applied Sciences (Germany)

7976 2J Dielectric elastomer actuators with enhanced permittivity and strain [7976-91]

H. Böse, D. Uhl, Fraunhofer-Institut für Silicatforschung (Germany); K. Flittner, H. Schlaak, Technische Univ. Darmstadt (Germany)

7976 2L PWM drive of IPMC actuators with the consideration of the capacitive impedance [7976-93] K. Takagi, Nagoya Univ. (Japan) and RIKEN (Japan); N. Yamaguchi, Nagoya Univ. (Japan); K. Asaka, AIST (Japan)

7976 2M Active suspension with multilayer dielectric elastomer actuator [7976-94]

R. Karsten, P. Lotz, H. F. Schlaak, Technische Univ. Darmstadt (Germany) 
7976 2N Low voltage driven dielectric electro active polymer actuator with integrated piezoelectric transformer based driver [7976-95]

T. Andersen, M. S. Rødgaard, O. C. Thomsen, M. A. E. Andersen, Technical Univ. of Denmark (Denmark)

797620 Ion distribution in ionic electroactive polymer actuators [7976-96]

Y. Liu, C. Lu, The Pennsylvania State Univ. (United States); S. Twigg, Villanova Univ. (United States); J. Lin, G. Hatipoglu, The Pennsylvania State Univ. (United States); S. Liu, Strategic Polymer Sciences, Inc. (United States); N. Winograd, Q. M. Zhang, The Pennsylvania State Univ. (United States)

7976 2Q Electromechanical fatigue in IPMC under dynamic energy harvesting conditions [7976-98] A. Krishnaswamy, D. Roy Mahapatra, Indian Institute of Science (India)

7976 2R DEA based neonatal lung simulator [7976-99] S. Schlatter, E. Haemmerle, R. Chang, B. M. O'Brien, T. Gisby, I. Anderson, The Univ. of Auckland (New Zealand)

797625 Open-loop control of IPMC actuators under varying temperatures [7976-100] R. Dong, X. Tan, Michigan State Univ. (United States)

7976 2T Influence of fabrication process steps on Pd-IPMC electrode morphologies and mechano-electrical properties [7976-101]

Z. Zhu, H. Chen, L. Chang, B. Li, Y. Wang, Xi'an Jiaotong Univ. (China)

$79762 \mathrm{~V} \quad$ New elastomeric silicone based networks applicable as electroactive systems [7976-104] A. G. Bejenariu, M. Boll, M. R. Lotz, C. Vraa, A. L. Skov, Technical Univ. of Denmark (Denmark)

$79762 \mathrm{~W}$ Induced interaction of $\mathrm{NH}_{4} \mathrm{NO}_{3}$ with poly(p-phenlene vinylene) by mean of zeolite $\mathrm{Y}$ [7976-107]

J. Kamonsawas, A. Sirivat, Chulalongkorn Univ. (Thailand); P. Hormnirun, Kasetsart Univ. (Thailand); W. Prissanaroon, KNITB (Thailand)

$79762 Z$ Biomimetic small scale variable focal length lens unit using synthetic elastomer actuators [7976-110]

B. Kim, J. Chung, Y. Lee, J.-D. Nam, H. Moon, H. R. Choi, J. C. Koo, Sungkyunkwan Univ. (Korea, Republic of)

797636 High actuation strain in silicone dielectric elastomer actuators with silver electrodes [7976-118]

S. H. Low, G. K. Lau, Nanyang Technological Univ. (Singapore)

797637 Ionic polymer-metal composite enabled robotic manta ray [7976-119]

Z. Chen, T. I. Um, H. Bart-Smith, Univ. of Virginia (United States)

797639 Experimental analysis of biasing elements for dielectric electro-active polymers [7976-122] M. Hodgins, S. Seelecke, Univ. of Saarland (Germany)

7976 3A Dynamic window daylighting systems: electropolymeric technology for solar responsive building envelopes [7976-123]

E. A. Krietemeyer, S. I. Smith, A. H. Dyson, Rensselaer Polytechnic Institute (United States) 
7976 3B Dielectric and insulating properties of an acrylic DEA material at high near-DC electric fields [7976-124]

L. Di Lillo, ETH Zurich (Switzerland); A. Schmidt, ETH Zurich (Switzerland) and EMPA

(Switzerland); A. Bergamini, EMPA (Switzerland); P. Ermanni, ETH Zurich (Switzerland);

E. Mazza, ETH Zurich (Switzerland) and EMPA (Switzerland)

Author Index 


\title{
Conference Committee
}

\author{
Symposium Chairs
}

Donald J. Leo, Virginia Polytechnic Institute and State University (United States)

Kara J. Peters, North Carolina State University (United States)

Symposium Cochairs

Norbert G. Meyendorf, Fraunhofer-Institut für Zerstörungsfreie Prüfverfahren (United States)

Norman M. Wereley, University of Maryland, College Park (United States)

Conference Chair

Yoseph Bar-Cohen, Jet Propulsion Laboratory (United States)

Conference Cochair

Federico Carpi, Università di Pisa (Italy)

Program Committee

Barbar J. Akle, Lebanese American University (Lebanon)

Tunku Ishak Al-Irsyad, University Teknologi MARA (Malaysia)

Siegfried Bauer, Johannes Kepler Universität Linz (Austria)

Ray Henry Baughman, The University of Texas at Dallas (United States)

Václav Bouda, Czech Technical University in Prague (Czech Republic)

Emilio P. Calius, Industrial Research Ltd. (New Zealand)

Suresh Chandra, Institute of Technology, Banaras Hindu University (India)

Toribio Fernández Otero, Universidad Politécnica de Cartagena (Spain)

Edwin W. H. Jager, Linköping University (Sweden)

Keiichi Kaneto, Kyushu Institute of Technology (Japan)

Jaehwan Kim, Inha University (Korea, Republic of)

Kwang J. Kim, University of Nevada, Reno (United States)

Roy D. Kornbluh, SRI International (United States)

Gabor M. Kovacs, EMPA (Switzerland)

Maarja Kruusmaa, University of Tartu (Estonia)

Jinsong Leng, Harbin Institute of Technology (China)

Wen-Liang Liu, Industrial Technology Research Institute (Taiwan) 
John David W. Madden, The University of British Columbia (Canada) Jae-Do Nam, Sungkyunkwan University (Korea, Republic of)

Siavouche Nemat-Nasser, University of California, San Diego (United States)

Qibing Pei, University of California, Los Angeles (United States)

Mehdi Razzaghi-Kashani, Tarbiat Modares University (Iran, Islamic Republic of)

Jonathan M. Rossiter, University of Bristol (United Kingdom)

Peter Sommer-Larsen, Risø National Laboratory (Denmark)

Anuvat Sirivat, Chulalongkorn University (Thailand)

Elisabeth Smela, University of Maryland, College Park (United States)

Ji Su, NASA Langley Research Center (United States)

Minoru Taya, University of Washington (United States)

Gordon G. Wallace, University of Wollongong (Australia)

Thomas Wallmersperger, Universität Stuttgart (Germany)

Gary Zaiats, Rafael Armament Development Authority Ltd. (Israel)

Qiming M. Zhang, The Pennsylvania State University (United States)

\section{Session Chairs}

1 EAP as Emerging Actuators

Yoseph Bar-Cohen, Jet Propulsion Laboratory (United States)

Federico Carpi, Università di Pisa (Italy)

2 Energy Harvesting Special Session: Part I

Siegfried G. Bauer, Johannes Kepler Universität Linz (Austria)

Roy D. Kornbluh, SRI International (United States)

3 EAP-in-Action Demonstration Session

Yoseph Bar-Cohen, Jet Propulsion Laboratory (United States)

4 Energy Harvesting Special Session: Part II

Zhigang Suo, Harvard University (United States)

Jonathan M. Rossiter, University of Bristol (United Kingdom)

5 European Scientific Network for Artificial Muscle (ESNAM) Special

Session: Energy Harvesting

Hans-Erik Kiil, Danfoss PolyPower A/S (Denmark)

Frederic Vidal, Université de Cergy-Pontoise (France)

6 ESNAM Special Session: Materials and Devices I

Peter Lotz, Technische Universität Darmstadt (Germany)

Guggi Kofod, Universität Potsdam (Germany)

Karl Kruusamäe, University of Tartu (Estonia) 
7a ESNAM Special Session: Materials and Devices II

Herbert R. Shea, Ecole Polytechnique Fédérale de Lausanne

(Switzerland)

Qibing Pei, University of California, Los Angeles (United States)

7b Field Activated EAP

Roy D. Kornbluh, SRI International (United States)

Jinsong Leng, Harbin Institute of Technology (China)

8a ESNAM Special Session: Materials and Devices III

Edwin W. H. Jager, Linköping University (Sweden)

Tissaphern Mirfakhrai, Stanford University (United States)

8b Ionic EAP

Keiichi Kaneto, Kyushu Institute of Technology (Japan)

Kwang J. Kim, University of Nevada, Reno (United States)

9a Haptic and Braille Displays I

Qiming M. Zhang, The Pennsylvania State University (United States)

Tushar K. Ghosh, North Carolina State University (United States)

9b Ionic EAP (continued)

Keiichi Kaneto, Kyushu Institute of Technology (Japan)

Kwang J. Kim, University of Nevada, Reno (United States)

10a Haptic and Braille Displays II

Helmut F. Schlaak, Technische Universität Darmstadt (Germany)

Marc Matysek, Philips Research Nederland B.V. (Netherlands)

10b Ionic EAP (continued)

Keiichi Kaneto, Kyushu Institute of Technology (Japan)

Kwang J. Kim, University of Nevada, Reno (United States)

11a ESNAM Special Session: Applications and Controls

Iain A. Anderson, The University of Auckland (New Zealand)

Juergen Maas, Ostwestfalen-Lippe Universität of Applied Sciences

(Germany)

11b Modeling and Analysis of EAP

Jonathan M. Rossiter, University of Bristol (United Kingdom)

Barbar J. Akle, Lebanese American University (Lebanon)

12a Applications of EAP I: Field Activated

Emilio P. Calius, Industrial Research Ltd. (New Zealand)

Tissaphern Mirfakhrai, Stanford University (United States) 
12b Non-EAP Actuators I

Ravi Shankar, Intel Corporation (United States)

Andrew T. Conn, University of Bristol (United Kingdom)

13a Applications of EAP I: Field Activated (continued)

Emilio P. Calius, Industrial Research Ltd. (New Zealand)

Tissaphern Mirfakhrai, Stanford University (United States)

13b Applications of EAP II: Ionic EAP

Thomas Wallmersperger, Technische Universität Dresden (Germany)

Hani E. Naguib, University of Toronto (Canada)

14a Applications of EAP I: Field Activated (continued)

Emilio P. Calius, Industrial Research Ltd. (New Zealand)

Tissaphern Mirfakhrai, Stanford University (United States)

14b Applications of EAP II: Ionic EAP (continued)

Thomas Wallmersperger, Technische Universität Dresden (Germany)

Hani E. Naguib, University of Toronto (Canada) 


\section{Introduction}

The SPIE Electroactive Polymers Actuators and Devices (EAPAD) conference is the leading international forum for presenting the latest progress and holding discussions among the attendees regarding the capabilities, challenges, and potential future directions. The conference this year was co-chaired by Federico Carpi, University of Pisa, Italy and included 124 presentations, which is the largest number of EAP related papers that have ever been submitted. EAP materials are increasingly attracting researchers from many fields for their large displacement and functional similarity to biological muscles.

The conference was well attended by internationally leading experts in the field including members of academia, industry, and government agencies from the USA and overseas. The keynote speaker was Thomas Sugar, Arizona State University, and the title of his presentation was "Walking with Springs". In his presentation he gave a review of his work related to the development of compliant wearable robots using tunable springs as well as robotic orthoses and prostheses for rehabilitation and mobility. He described spring ankle with regenerative kinetics and a powered ankle foot orthosis for stroke rehabilitation.

Turning EAP into actuators-of-choice requires solidifying the technical foundations and identifying niche applications taking advantage of their unique capabilities to provide edge for critical needs. Significant progress was reported in each of the topics of the EAP infrastructure with focus on such areas as energy harvesting, biomimetics, haptics, braille displays, and miniaturization. The papers addressed issues that can forge the transition to practical use, including improved materials, better understanding of the principles responsible for the electromechanical behavior, analytical modeling, processing and characterization methods as well as considerations and demonstrations of various applications. Two special sessions were dedicated this year to the topic of energy harvesting. Moreover, the conference included four special sessions grouping contributions from members of the European Scientific Network for Artificial Muscle (ESNAM). One of these sessions was also dedicated to energy harvesting. Other topics that were covered in this conference included:

- Electroactive polymers (EAP) and non-electro active-polymer (NEAP) materials

- Theoretical models, analysis and simulation of EAP

- Methods of testing and characterization of EAP

- EAP as artificial muscles, actuators and sensors

- Design, control, intelligence, and kinematic issues related to robotic and biomimetic operation of EAP

- Under consideration and in progress applications of EAP 
The efforts described in the presented papers are showing significant improvements in understanding of the electromechanical principles and better methods of dealing with the challenges to the materials applications. Researchers are continuing to develop analytical tools and theoretical models to describe the electro-chemical and-mechanical processes, non-linear behavior as well as methodologies of design and control of the activated materials. EAP with improved response were described including dielectric elastomer, IPMC, conductive polymers, gel EAP, carbon nanotubes, and other types. Specifically, there seems to be a significant trend towards using dielectric elastomers as practical EAP actuators.

This year, the EAP-in-Action session was held on Monday, March 7, 2011 and included seven demonstrations from Benjamin Thomsen, Danfoss PolyPower A/S (Denmark); P. Lotz, Technische Univ. Darmstadt (Germany); M. Matysek, Philips Research Nederland B.V. (Netherlands); H. Haus, Technische Univ. Darmstadt (Germany); H. Moessinger, D. Brokken, Philips Research Nederland B.V. (Netherlands); H. F. Schlaak, Technische Univ. Darmstadt (Germany); Federico Carpi, Univ. of Pisa, Research Centre "E. Piaggio" (Italy); lain Anderson, Emilio Calius, Todd Gisby, Andrew Lo, Thomas McKay, Ben O'Brien, Tony Tse, The Biomimetics Lab of the Auckland Bioengineering Institute (New Zealand); Marcus Rosenthal, Artificial Muscle, Inc. (United States); Qibing Pei, Univ. of California, Los Angeles (United States); and Lenore Rasmussen, Ras Labs. LLC (United States).

To provide the attendees with opportunity to learn about EAP, an introductory course was given on Sunday, March 6,2011 as part of the EAPAD conference. The course was entitled "Electroactive Polymer Actuators and Devices," and the lead instructor was the conference chair, Yoseph Bar-Cohen, who presented an overview and covered applications that are currently developed and ones that are being considered. The subject of Ionic EAP was covered by John D. W. Madden, the Univ. of British Columbia, Canada, while the topic of Electronic EAP was covered by Qibing Pei from the University of California at Los Angeles (UCLA).

In closing, we would like to extend a special thanks to all the conference attendees, session chairs, the EAP-in-Action demo presenters, the members of the EAPAD program organization committee. In addition, special thanks are extended to the SPIE staff that helped making this conference a great success.

\section{Yoseph Bar-Cohen Federico Carpi}

